\title{
A water budget approach to predicting tree species growth and abundance, utilizing paleoclimatology sources
}

\author{
James M. Dyer* \\ Department of Geography, Ohio University, Athens, Ohio 45701, USA
}

\begin{abstract}
Biogeographers and ecologists often need to quantify species-environment relationships to understand the distribution of vegetation, and to assess changes in patterns resulting from environmental change. A water budget approach, which incorporates evaporative demand and moisture availability, is compared to traditional climatic variables in terms of ability to predict species growth and abundance in eastern North America. Firstly, tree growth is examined using tree-ring chronologies obtained from the International Tree-Ring Data Bank, correlated with climatic data from the nearest site in the US Historical Climatology Network. Secondly, logistic regression is used to model the range of American beech (Fagus grandifolia) using pollen records from the World Data Center for Paleoclimatology, and climatic data from NCAR's Community Climate Model (CCM1) general circulation model (GCM) for the control, $6 \mathrm{ka}$, and $11 \mathrm{ka}$ runs. Tree growth, especially for oaks and other deciduous trees, correlates more strongly with early growing-season deficit than with precipitation. Water budget variables (actual evapotranspiration and deficit) are also more effective than traditional climatic variables in modeling the range of beech. A water budget approach is attractive for modeling vegetation dynamics because it transcends geographic scale; it is able to model both local and continental-scale phenomena.
\end{abstract}

KEY WORDS: Water budget $\cdot$ Pollen $\cdot$ Tree rings $\cdot$ General circulation model $\cdot$ Scale $\cdot$ Beech

\section{INTRODUCTION}

Vegetation patterns emerge through the interaction of 3 templates: the physical environment, biotic processes, and disturbance. At broad spatial scales, the physical environment, especially climate, has long assumed primacy in explaining distributional patterns (e.g. Merriam 1894, Holdridge 1947). Given the prospect of future climate change, the accurate quantification of species-environment relationships is critical for assessing potential vegetation responses. A water budget approach, which incorporates evaporative demand and moisture availability, has proven useful in delineating vegetation formations (e.g. deciduous forest, tallgrass prairie; Mather \& Yoshioka 1968, Stephenson 1990), and in understanding climatic controls on forest regeneration (Savage et al. 1996). A water budget approach has less frequently been used to delineate individual species ranges (e.g. Manogaran 1975), although previous work by Dyer (2002) has demonstrated its ability to predict the occurrence of a single species within a forest stand. The present study extends this approach by comparing water budget variables with traditional climatic variables in their ability to model species responses at broad spatial scales using readily available paleoclimatic data sources. In Section 2, tree-ring chronologies are used to explore the relationship between climate and growth rates. This was prompted by the question: what climatic variable most strongly controls tree growth in the eastern forests of the USA? Dendroclimatological studies often use stepwise multiple regression to derive a suite of climatic variables most strongly linked to growth at an individual study site; however, results 
between such studies often differ. This research looks at many tree-ring chronologies from the eastern USA in an attempt to uncover the climatic variable that consistently exhibits the strongest correlation with tree growth.

Section 3 of the paper describes the use of fossil pollen records to explore the link between climate and species abundance in eastern North America. The ability to accurately delineate species ranges has direct bearing on efforts to understand climatic change on biotic communities.

\section{CLIMATE AND TREE GROWTH}

\subsection{Background}

Climate plays a critical role in controlling species range limits, relative abundance, and growth, yet this relationship can manifest itself in many ways (e.g. MacDonald 2003). For example, range limits may be controlled by annual temperature extremes, by conditions during the growing season, or conditions during the previous year. To evaluate which climatic variables most strongly correlate with growth, tree-ring chronologies in the eastern USA were correlated with climatic variables derived from nearby weather stations; both water budget variables and raw temperature and precipitation values were examined. The Palmer Drought Severity Index (PDSI; Palmer 1965) also was examined. Although it is an 'index' using arbitrarily selected criteria to define the length of a drought or wet spell (Alley 1984), the PDSI incorporates raw climatic and water budget variables, and is widely used in dendroclimatology.

In areas that experience seasonal climates, tree rings can be used as indicators of past climatic conditions. Dendrochronologists select individual trees to core in order to maximize a particular signal (for example moisture stress), so that growth rates can serve as a proxy for a variable of interest (such as precipitation). Data from several trees at a site can be combined to form a chronology, utilizing a standardization procedure to remove growth trends. This standardization procedure involves fitting a curve to the ring-width series and then dividing each ring-width value by the corresponding curve value (Fritts 1976).

\subsection{Methods}

Tree-ring chronologies were downloaded for the eastern USA (233 sites east of $100^{\circ} \mathrm{W}$; Fig. 1) from the International Tree-Ring Data Bank (WDC 2003a). These records represent chronologies generated and contributed by dozens of research scientists; taken together, they provide a broad-scale catalog of tree growth, though the original samples may not necessarily have been collected for climatic reconstruction purposes. ARSTAN chronologies (AutoRegressive STANdardization; Cook \& Holmes 1999) were used for all records; index values are unitless with 1000 representing the long-term mean. Higher or lower values for a given year represent proportionally higher or lower tree growth for that year.

Climate data were obtained from the US Historical Climatology Network (HCN; see Fig. 1). This data set of monthly averaged maximum, minimum, and mean temperatures and total monthly precipitation was developed to assist in the detection of regional climate change (Karl et al. 1990). Tree-ring chronologies were assigned the climatic values of the closest $\mathrm{HCN}$ site with both temperature and precipitation data. The average distance between a tree-ring site and a weather station was $37 \mathrm{~km}$; 202 tree-ring sites were within $60 \mathrm{~km}$ of an HCN site, 29 were 60 to $120 \mathrm{~km}$, and 2 were 120 to $150 \mathrm{~km}$ from their corresponding weather station. Since tree-ring sites are often in close proximity to other tree-ring sites (93 sites were within $25 \mathrm{~km}$ of another site), in some instances the same HCN site was assigned to multiple tree-ring sites (128 weather stations were assigned to the 233 tree-ring chronologies; see Fig. 1). Years with any missing monthly climatic data were excluded from the analysis. The average for all tree-ring sites was 109 yr of weather data; the oldest climatic record extended back to 1835 .

Monthly temperature and precipitation values were used to estimate actual evapotranspiration (AET, evaporative water loss from a site), and deficit (evaporative demand not met by available water), using the WATBUG program (Willmott 1977), a single soil-layer model which relies on the Thornthwaite (1948) method of calculating potential evapotranspiration (PET). Available water capacity (AWC) in the top $150 \mathrm{~cm}$ of the soil profile was estimated for each tree-ring site, based on the US Department of Agriculture-Natural Resources Conservation Service State Soil Geographic Database (STATSGO) (Miller \& White 1998). AET was assumed to decline linearly with soil moisture content, since the rate of evapotranspiration decreases as the soil dries (Mather 1974).

Monthly temperate and precipitation data were also used to compute the PDSI for each tree-ring site (Wells [2003] PDSI users manual, Version 2. University of Nebraska-Lincoln National Agricultural Decision Support System. Available at: http://nadss.unl.edu). The PDSI is a 2 soil-layer model using a water budget approach (also relying on the Thornthwaite (1948) method of calculating PET) to compare changes in the moisture supply. Based on historic conditions at a site, 


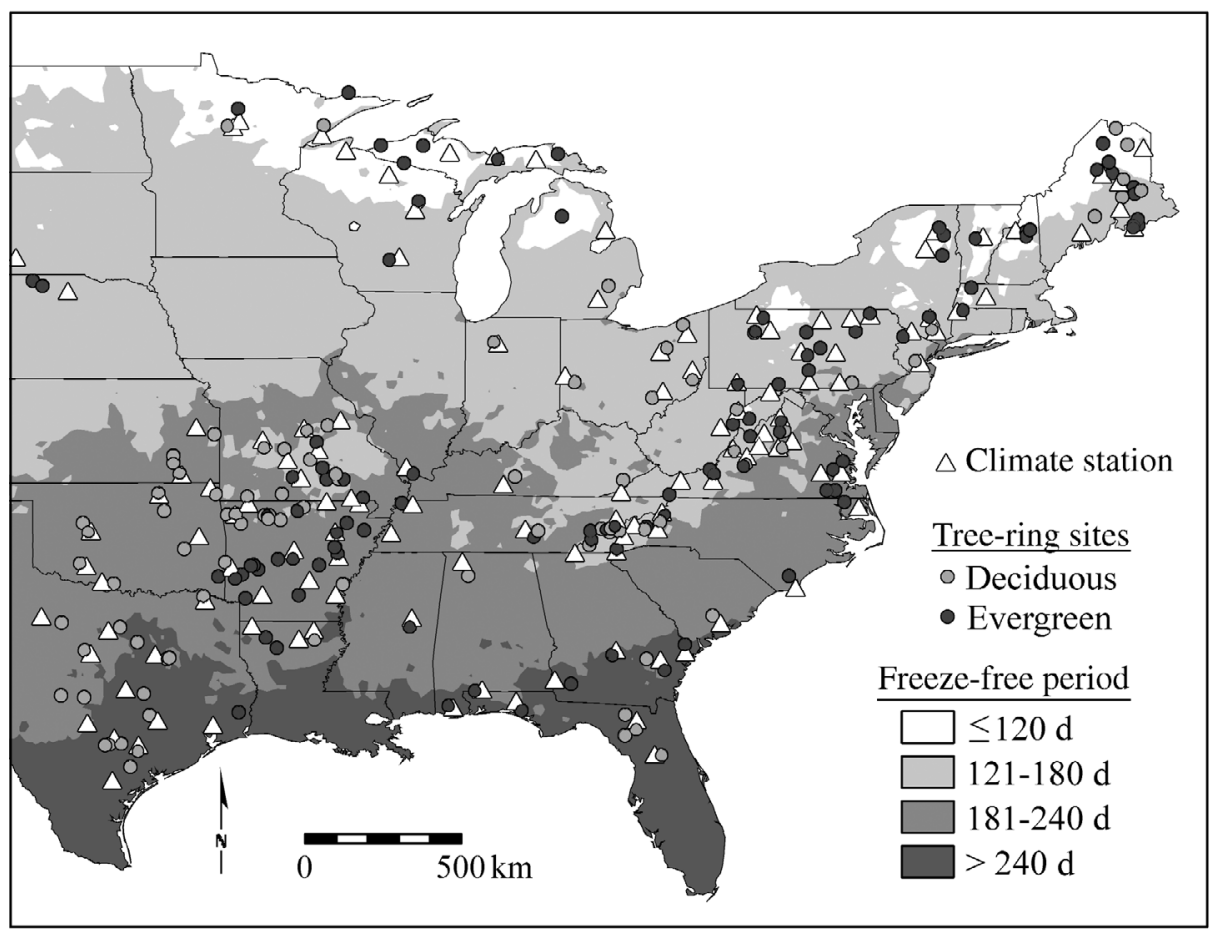

Fig. 1. Map of mean freeze-free period, showing Historical Climatology Network and tree-ring chronology sites

a PDSI of 0 represents normal conditions, while drought is indicated by increasingly negative values, and positive values indicate increasingly wet conditions. To compute the index, STATSGO was again used to estimate AWC in the top $150 \mathrm{~cm}$ of the soil profile for each tree-ring site (Miller \& White 1998).

Climatic variables used in the correlation analysis with tree growth were monthly and annual values of mean temperature, precipitation, AET, deficit, and the PDSI. These values were also lagged 1 yr to assess the relationship between tree growth and climatic conditions during the previous year. Climatic variables were also assessed for the growing season, variously defined as May-June, June-July, and May-July; precipitation, evapotranspiration, and deficit values were summed over annual and seasonal time periods, and temperature and PDSI values were averaged.

\subsection{Results}

Pearson correlation coefficients for tree-ring width and key climatic variables are reported in Table 1; highest correlations observed were $<0.35$. Obviously, regional climate alone is not controlling growth rates of individual trees; competition, formation of canopy gaps, and microclimate all may strongly control a tree's growth pattern. The statistical significance of the climatic relationships substantiates the conclusion that climate does influence tree growth, however, and the magnitude of the bivariate relationships reported here are on a par with results from other areas within the eastern deciduous forest ( $H$. Grissino-Mayer pers. comm., J. Speer pers. comm.). The magnitude of the correlation coefficients remained virtually unchanged when the analysis included only pollen sites within $60 \mathrm{~km}$ of a weather station.

For all tree-ring chronologies combined, moisture availability emerged as the critical limiting factor, an intuitive result for trees of the eastern forest. Additionally, it is evident that trees respond most strongly to water stress early in the growing season (Table 1). Similar results emerged when the data were analyzed in subsets: moisture, especially deficit, in May-June was most strongly correlated with growth for both evergreen and deciduous trees, though the relationship was stronger for the deciduous trees. Growth in oaks especially correlated highly with early growing season deficit (Table 1).

Soil moisture deficit, which accounts for moisture supply and demand, correlated slightly higher with tree growth than did growing-season precipitation; obviously there is a correlation between deficit and precipitation (e.g. the correlation coefficient between deficit and precipitation for May-June was -0.49), but soil moisture deficit is a more biologically meaningful variable, since it offers a direct assessment of water use and soil moisture storage. Since the Thornthwaite 
Table 1. Pearson correlation coefficients for variables most strongly correlated with tree growth, for all species $(\mathrm{n}=233$ chronologies), evergreen ( $\mathrm{n}=124)$, all deciduous $(\mathrm{n}=109)$, and oaks $(\mathrm{n}=89)^{\mathrm{a}}$. Water stress in the early growing season correlates most strongly with tree-ring width. May-June deficit (bold) correlates more highly than raw precipitation. All values are significant at $\mathrm{p}<0.0001$. PDSI: Palmer Drought Severity Index

\begin{tabular}{|c|c|c|c|c|}
\hline \multirow{2}{*}{$\begin{array}{l}\text { Variable } \\
\text { May deficit }\end{array}$} & All & $\begin{array}{r}\text { Ring } \\
\text { Evergreen }\end{array}$ & $\begin{array}{l}\text { idth } \\
\text { Peciduous }\end{array}$ & s Oaks \\
\hline & -0.17 & -0.17 & -0.20 & -0.23 \\
\hline Jun deficit & -0.21 & -0.20 & -0.26 & -0.29 \\
\hline Jul deficit & -0.14 & -0.15 & -0.16 & -0.18 \\
\hline May-Jun deficit & -0.23 & -0.22 & -0.27 & -0.31 \\
\hline May-Jul deficit & -0.20 & -0.21 & -0.23 & -0.27 \\
\hline Jun-Jul deficit & -0.19 & -0.19 & -0.22 & -0.25 \\
\hline Annual deficit & -0.15 & -0.17 & -0.18 & -0.20 \\
\hline May precipitation & 0.15 & 0.14 & 0.17 & 0.20 \\
\hline Jun precipitation & 0.17 & 0.15 & 0.19 & 0.21 \\
\hline Jul precipitation & 0.06 & 0.06 & 0.05 & 0.06 \\
\hline May-Jun precipitation & 0.20 & 0.20 & 0.24 & 0.28 \\
\hline May-Jul precipitation & 0.20 & 0.19 & 0.22 & 0.25 \\
\hline Jun-Jul precipitation & 0.14 & 0.14 & 0.15 & 0.17 \\
\hline Annual precipitation & 0.12 & 0.10 & 0.15 & 0.18 \\
\hline May PDSI & 0.21 & 0.17 & 0.26 & 0.30 \\
\hline Jun PDSI & 0.24 & 0.20 & 0.30 & 0.34 \\
\hline Jul PDSI & 0.23 & 0.19 & 0.28 & 0.31 \\
\hline May-Jun PDSI & 0.23 & 0.19 & 0.29 & 0.33 \\
\hline May-Jul PDSI & 0.24 & 0.20 & 0.30 & 0.34 \\
\hline Jun-Jul PDSI & 0.24 & 0.20 & 0.30 & 0.34 \\
\hline Annual PDSI & 0.21 & 0.18 & 0.25 & 0.30 \\
\hline \multicolumn{5}{|c|}{$\begin{array}{l}\text { a'The } 233 \text { tree-ring chronologies were developed using the } \\
\text { following species: Quercus alba (24), Q. lyrata (4), Q. prinus } \\
\text { (9), Q. rubra (2), Q. stellata (48), Q. velutina (1), Quercus sp. } \\
\text { (1), Acer saccharum (1), Castanea dentata (9), Fraxinus } \\
\text { nigra (6), Liriodendron tulipifera (4), Juniperus virginiana } \\
\text { (10), Picea rubens (12), Pinus echinata (8), P. palustris (4), P. } \\
\text { ponderosa (2), P. pungens (1), P. resinosa (4), P. rigida (2), P. } \\
\text { strobus (9), Taxodium distichum (28), Thuja occidentalis (1), } \\
\text { Tsuga canadensis (42), and T. caroliniana (1) }\end{array}$} \\
\hline
\end{tabular}

water budget approach serves as the basis for the PDSI, it is not surprising that correlations between tree-ring width and PDSI were similar to correlations seen with deficit (Table 1). An advantage of the PDSI is that the index is standardized to local climate; this also poses a limitation in that at least $25 \mathrm{yr}$ of climatic data are needed to calculate the index. In contrast, a water budget can be balanced over a $1 \mathrm{yr}$ period (even though balancing occurred over all years in this study). When multiple years of climatic data are unavailable (as in Section 3), deficit is a more appropriate climatic variable.

The seasonal relationship between deficit and tree growth may be expected to differ latitudinally, since the onset and total length of the growing season increases toward the equator. When the correlation analysis was performed by frost zone (Fig. 1); however, May-June moisture stress still emerged as a critical limiting factor to tree growth, though the strength of the relationship generally increased as growing season length increased (Table 2). Interestingly, at those sites with the shortest growing season ( $\leq 120 \mathrm{~d}$ ), deficit during the previous year showed a higher correlation than current growing season deficit with tree growth. However, a latitudinal pattern did emerge with AET. At sites with the longest growing season (>240 d), MayJune AET was most strongly correlated with tree growth, whereas July AET correlated most strongly with tree growth at sites with a mean freeze-free period of $180 \mathrm{~d}$ or less (Table 2). Temperature variables did not correlate significantly with tree growth.

\section{RANGE MODELING}

\subsection{Background}

In forests of eastern USA, soil moisture deficit influences growth rates of individual trees. At coarser scales-for instance, examining vegetation responses to climate change-the focus is often on species presence/absence, rather than growth rates. Species ranges have changed dramatically in the past in response to climatic changes (e.g. Jacobson et al. 1987). To determine whether relationships established between tree growth and climate hold at broader spatial scales, and to compare water budget variables with other climatic variables in predicting species presence at coarser scales, this analysis compared changing species range maps derived from fossilized pollen records, to past climatic conditions derived from a general circulation model (GCM).

Approaches to predicting vegetation responses to altered climate can be categorized as 'dynamic' or 'equilibrium'. Dynamic approaches (such as forest stand simulation models) simulate establishment, growth, and mortality on small plots. Equilibrium approaches assume that vegetation is in equilibrium with climate, and rely on this correlative relationship to model

Table 2. Pearson correlation coefficients for tree-ring width and water budget variables by mean annual freeze-free period. All values are significant at $\mathrm{p}<0.0001$

\begin{tabular}{|c|c|c|c|}
\hline \multirow{2}{*}{$\begin{array}{l}\text { Freeze-free } \\
\text { period }\end{array}$} & \multicolumn{2}{|c|}{ Moisture stress } & \multirow{2}{*}{$\begin{array}{c}\text { Actual } \\
\text { evapotranspiration }\end{array}$} \\
\hline & $\begin{array}{c}\text { May-Jun } \\
\text { deficit }\end{array}$ & $\begin{array}{l}\text { Previous year } \\
\text { annual deficit }\end{array}$ & \\
\hline$\leq 120 \mathrm{~d}(\mathrm{n}=28)$ & -0.11 & -0.15 & 0.10 (Jul) \\
\hline $121-180 \mathrm{~d}(\mathrm{n}=107)$ & -0.19 & -0.10 & 0.15 (Jun-Jul) \\
\hline $181-240 \mathrm{~d}(\mathrm{n}=72)$ & -0.30 & -0.07 & 0.20 (Jun-Jul) \\
\hline$>240$ d $(\mathrm{n}=26)$ & -0.28 & -0.05 & 0.21 (May-Jun) \\
\hline
\end{tabular}


species' distributions. Equilibrium approaches have been criticized because (1) they do not account for transient responses to climate change, (2) they are based on correlations between climate and a species' realized niche, (3) they do not include localized effects such as topography and soils, and (4) present-day correlations may not hold under altered climates (e.g. Loehle \& LeBlanc 1996, Roth 1996). However, such approaches are useful in dealing with the intractable issue of modeling localized processes at regional or continental scales. Moreover, acknowledging the primacy of climate in controlling species distributions, it is still necessary to assess which climatic variables most strongly influence vegetation. Careful consideration of variables in an equilibrium approach can identify biologically meaningful variables (that may integrate topographic and edaphic effects), which can then be incorporated into dynamic modeling approaches.

Equilibrium approaches to predicting vegetation responses to altered climate fall into one of the following categories: (1) Climate-range correlations determine the value of several key climatic variables coincident with current range limits (e.g. the 'climatic envelopes' method of Box 1981, which uses the maximum and minimum values of 8 climatic variables); altered climate scenarios are evaluated by delimiting the geographic displacement of the presumed climatic controls. Many of these climatic variables are strongly intercorrelated, however, and Cramer \& Leemans (1993) concluded that fewer well-selected variables might perform just as well, and be more easily tested and interpreted. (2) Response surfaces relate some measure of taxon abundance to a weighted combination of climatic variables. Many well-cited examples of response surfaces initially used combinations of 3 climatic variables to delineate ranges: mean January and July temperatures, and total annual precipitation (e.g. Bartlein et al. 1986, Huntley et al. 1989, Overpeck et al. 1991, Davis \& Zabinski 1992). Despite the assertion that results would not be changed significantly with other variables (Overpeck et al. 1991), the trend has been to use 'bioclimatic' variables that more directly relate to growth, reproduction, and survival of plants (e.g. Lenihan 1993, Shafer et al. 2001).

This study uses a response surface approach to evaluate the ability of 3 sets of variables to delineate the range of a tree species: Model $1=$ AET and deficit (Stephenson 1998, Dyer 2002); Model 2 = mean temperature of the coldest month $\left(T_{\min }\right)$, growing degree days (GDD), and a moisture index (AET/PET) (after Shafer et al. 2001, but using a different source for soil AWC); and Model 3 = mean January and July temperature, and annual precipitation (Overpeck et al. 1991, Davis \& Zabinski 1992).

\subsection{Methods}

\subsubsection{Pollen database}

Pollen records were obtained from the North American Pollen Database (WDC 2003b) for eastern North America (east of $100^{\circ} \mathrm{W}$, north to $60^{\circ} \mathrm{N}$ ). The 'Fossil 70' record (containing percentage data for 71 designated taxa) was obtained for each site. For each record, pollen data were extracted for the presettlement period, 400 to $600 \mathrm{yr}$ before the present (hereafter designated as $500 \mathrm{BP}$ ), as well as for $1000 \mathrm{yr}$ increments from 1000 to $11000 \mathrm{yr}$ ago (designated as $1 \mathrm{ka}, 2 \mathrm{ka}$, etc.). The cut-off values for these $1000 \mathrm{yr}$ periods was $\pm 500 \mathrm{yr}$ (e.g. the $11 \mathrm{ka}$ record included pollen data for 10500 to $11500 \mathrm{yr}$ ago); if a sample had multiple pollen records for a given $1000 \mathrm{yr}$ period, that closest to the millennial mark was selected for analysis.

Many arboreal taxa are identified only to genus in the database (e.g. 'oak'), which can lead to ambiguities in establishing climate-range relationships. Considering arboreal taxa in the eastern North America, there are 4 monospecific genera included in the Fossil 70 records: Castanea (chestnut), Fagus (beech), Liquidambar (sweetgum), and Platanus (sycamore). Only beech and sycamore were present at a large number of sites $(>10 \%)$ across the time periods. Being a tree associated with riparian settings, sycamore was not considered an ideal candidate to explore climate-range relationships. American beech was thus selected as the target species for this analysis.

Beech was also chosen for the analysis because it is a late-successional species (the only species of the 4 listed above to be classified as 'very tolerant' of shade; Burns \& Honkala 1990); since it is a good competitor, it might therefore be hypothesized that beech occupies a larger proportion of its fundamental niche, so that climatic variables could accurately delineate its range limits (see Pearson \& Dawson 2003). Beech is also a good candidate for analysis because it is a dominant species in a number of forest cover types (Eyre 1980), its pollen rain has been shown to be a good predictor of beech presence (Davis et al. 1986), and it has been the subject of numerous global change studies, including those exploring the potential consequences of climatic warming (e.g. Davis \& Zabinski 1992), and those examining vegetation responses since the last glaciation (e.g. Huntley et al. 1989).

Fig. 2 shows changing beech abundance and distribution since $11 \mathrm{ka}$. In the statistical analysis, fossil pollen percentages $\geq 0.5 \%$ were considered evidence that the site was within the range of beech (Davis et al. 1986). 


\subsubsection{General circulation model}

Data for climatic reconstructions were derived from NCAR's Community Climate Model (CCM1), a 3- dimensional global atmospheric model for use in analysis of global climate (Williamson et al. 1987). Monthly temperature, precipitation, and solar insolation at the surface were obtained for each point in the
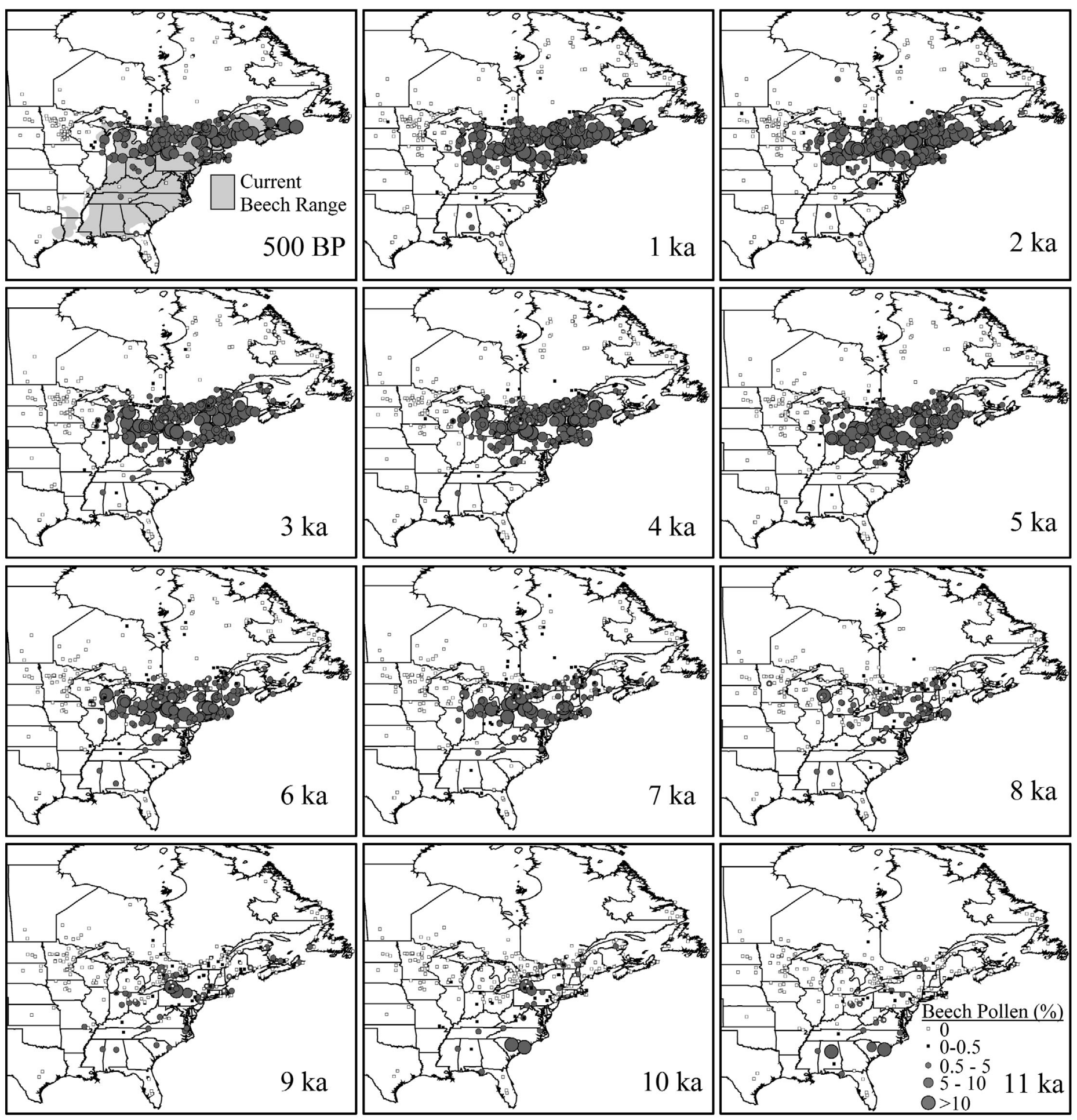

Fig. 2. Changing beech abundance and distribution from $11000 \mathrm{yr}$ ago to the presettlement period (500 BP). Current beech range from Little (1971). Note that pollen sites are sparse in the south 
grid (roughly $4.5^{\circ}$ latitude $\times 7.5^{\circ}$ longitude), and interpolated to a $0.5^{\circ}$ grid using a spline function in ArcView. Data were obtained for a control run (corresponding to the presettlement pollen strata), $6 \mathrm{ka}$, and $11 \mathrm{ka}$. Atmospheric $\mathrm{CO}_{2}$ concentration is $267 \mathrm{ppm}$ for all 3 runs.

\subsubsection{Derivation of climatic and soil variables}

Interpolated values of temperature, precipitation, and solar insolation were assigned to each pollen site. PET was estimated for each site using the Turc formula (Turc 1961, in ASCE 1990):

$$
\mathrm{PET}=0.013[T /(T+15)]\left(R_{\mathrm{S}}+50\right)
$$

where PET is the monthly potential evapotranspiration in $\mathrm{mm}, T$ is the normal monthly temperature in ${ }^{\circ} \mathrm{C}$, and $R_{\mathrm{s}}$ is the monthly global radiation received at the earth's surface on a horizontal plane, in cal $\mathrm{cm}^{-2}$. The Turc method provides good estimates of both seasonal and peak evapotranspiration in humid climates (ASCE 1990), and was chosen because it requires only average temperature and solar radiation as input variables (both of which differ from present-day conditions at 6 and $11 \mathrm{ka}$ ). The Thornthwaite method of estimating $\mathrm{PET}$, which employs empirically derived equations to compute the 'heat index' of each site, may not be appropriate under the 6 and 11 ka scenarios. An estimate of soil water holding capacity for each pollen site was derived from the UNESCO Soil Map of the World at a $1^{\circ} \times 1^{\circ}$ resolution (Bouwman et al. 1993).

Once values of PET, precipitation, and soil moisture storage were obtained, AET, deficit, and surplus were computed for each site (Mather 1974). Daily computations were performed to arrive at a single monthly value (corresponding to the last day of each month). Evapotranspiration was assumed to decline linearly with soil moisture content, since the rate of evapotranspiration decreases as the soil dries (Mather 1974).

Lastly, GDD for each pollen site was derived by estimating daily normals from monthly normal temperatures using a cubic spline function (Greville 1967); original monthly values are preserved. GDD was computed using a $5^{\circ} \mathrm{C}$ base (i.e. the number of degrees above $5^{\circ} \mathrm{C}$ of each day's temperature was summed over the entire year).

\subsubsection{Statistical analysis}

Logisitic regression was used to relate the binary response variable (presence/absence of beech) to the climatic predictors for the presettlement condition (i.e. 500 BP pollen, and control run of the GCM). By using the maximum likelihood estimates of the regression parameters, the probability of beech presence can be calculated for different values of the climatic variables. The threshold probability for declaring beech to be present was 0.500. Statistically significant ( $p<0.05$ for parameter estimates) regression models were applied to 6 and $11 \mathrm{ka}$ pollen and climate scenarios to assess their accuracy in predicting beech presence under altered climate conditions. Logistic regression was performed using SAS version 8 (SAS Institute 1999).

To evaluate model performance in a spatial context, the study area was divided into a $0.5^{\circ} \times 0.5^{\circ}$ grid, corresponding to the interpolated climatic grid. For each time period, individual cells were assigned a value of 'presence' if any pollen site within the cell registered a presence $(\geq 0.5 \%$ pollen) of beech. Cells were assigned a value of 'absence' if all of the pollen sites within them recorded an absence of beech. Range limits of observed beech and modeled beech could then be delimited for each time period.

\subsection{Results}

Parameter estimates for regression Model $2\left(T_{\min }\right.$ GDD, and AET/PET) and Model 3 (mean January and July temperature, and annual precipitation) were not statistically significant. Results for Model 1 (AET and deficit) are presented in Table 3, and in Fig. 3.

In the 500 BP scenario, for which the model was calibrated, a fairly close correspondence can be seen between modeled and observed grid cells with beech presence (97 of 105 cells with presence are correctly modeled). The modeled eastern range limit extends to the Atlantic coast, corresponding with the present-day range limit, and the western range limit is also accurately modeled (cf. the present-day distribution of beech in Fig. 2). One site in central Quebec extends

Table 3. Logistic regression classification results for Model 1 (annual deficit, AET). ka: 1000 yr increment (see Section 3.2); correct: percentage of sites accurately modeled; sensitivity: percentage of predicted 'presence' that were actually 'presence'; specificity: percentage of predicted 'absence' that were actually 'absence'; false positive: percentage of 'presence' incorrectly predicted to be 'absence'; false negative: percentage of actual 'absence' incorrectly predicted to be 'presence'

\begin{tabular}{|lccccc|}
\hline $\begin{array}{l}\text { Time } \\
\text { period }\end{array}$ & Correct & Sensitivity & Specificity & $\begin{array}{c}\text { False } \\
\text { positive }\end{array}$ & $\begin{array}{c}\text { False } \\
\text { negative }\end{array}$ \\
\hline $500 \mathrm{BP}$ & 81 & 75 & 90 & 8 & 31 \\
$6 \mathrm{ka}$ & 67 & 54 & 95 & 4 & 52 \\
$11 \mathrm{ka}$ & 72 & 18 & 95 & 38 & 27 \\
\hline
\end{tabular}


the modeled range further north than is observed. Several pollen sites in the south record an absence of beech in the region at $500 \mathrm{BP}$, even though they fall within the present-day range limit of beech (see Fig. 2); the model predicts these southern sites to fall within the range of beech. In the 6 ka scenario, 103 of 107 cells with beech presence are correctly modeled, though the model erroneously extends the range limit of beech west of the Great Lakes, and the northern range is several hundred kilometers poleward of the observed range. In the $11 \mathrm{ka}$ scenario, beech is correctly predicted to be present at 10 of the 16 sites with observed beech presence. The model predicts beech to be present in the Great Lakes region east of Lake Superior (where there are pockets of observed beech), extending to the southeastern coast (beech is most abundant in the south; see Fig. 2). The model correctly predicts beech presence in all but 2 sites in the south.
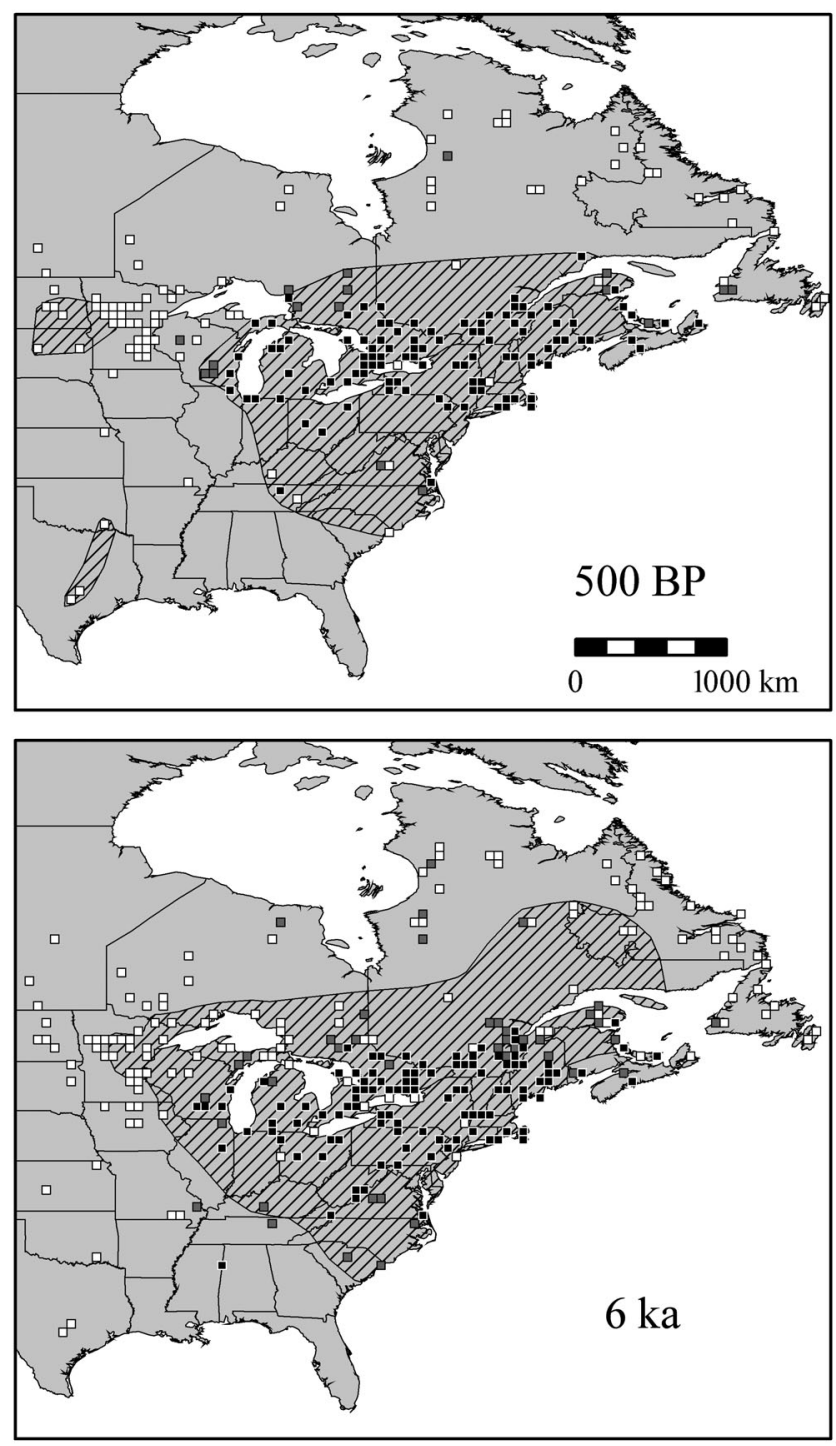

\section{SUMMARY AND CONCLUSIONS}

Although the link between moisture stress and tree growth has long been realized, the specific variables most strongly correlated with tree growth in forests of the eastern USA have not been clear. The present study has indicated that trees respond to water deficit during the early growing season; the relationship is strongest with oaks and other deciduous species, especially in areas experiencing a longer growing season. In areas with the shortest growing season, trees respond more to annual deficit of the previous year. AET during the growing season was also positively correlated with tree growth, though temperature was not.

These 2 biologically meaningful variables, deficit and AET, which incorporate moisture demand, availability, and utilization in a biologically meaningful way, are

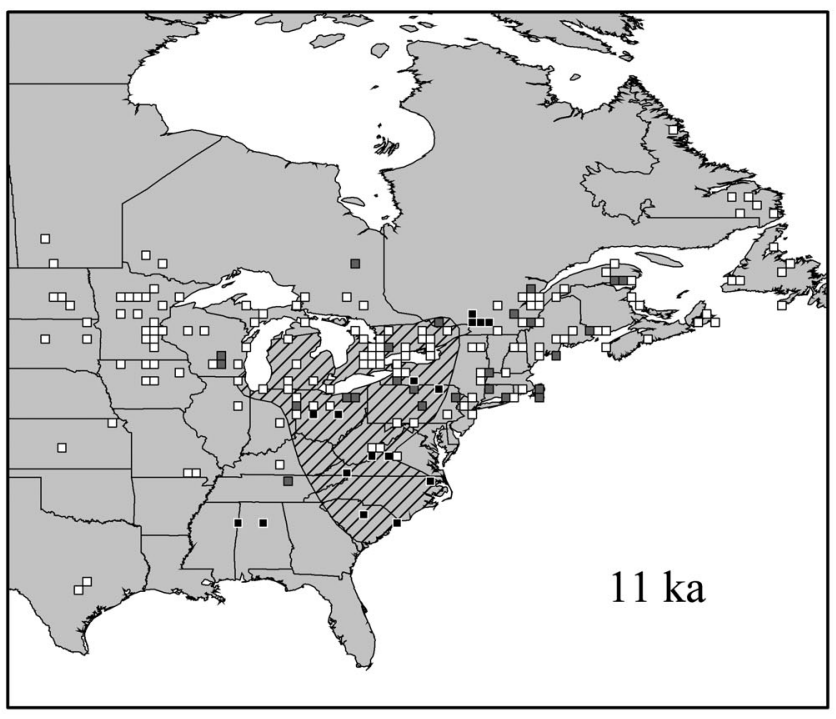

$\underline{0.5^{\circ} \times 0.5^{\circ} \text { Grid Cells }}$ Beech Pollen:

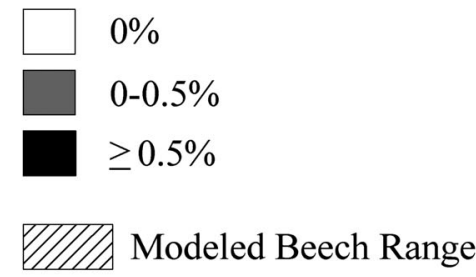

Fig. 3. Grid cells used as observations for the logistic regression with annual AET (actual evapotranspiration) and deficit as explanatory variables. Each grid cell is assigned the value of the pollen site with the highest beech percentage that falls within it. In the regression analysis, only cells with $\geq 0.5 \%$ beech pollen were considered to have a presence of beech. The hachured envelope circumscribes grid cells that the model classified as having beech present 
also shown to predict the range of a single species, i.e. beech. Unlike the tree-ring analysis, May-June AET and deficit did not perform as well as annual values in delineating the range of beech. This could be attributable to the inability of the GCM to accurately model seasonal variations in climatic parameters, or perhaps annual values are superior in predicting establishment, as opposed to growth. Use of annual values is appealing, since the timing of seasonal moisture demand may change under altered climate scenarios.

When the model was applied to the $6 \mathrm{ka}$ scenario, there was correspondence between the modeled and observed presence of beech, though the modeled range was several hundred kilometers poleward of the observed range. NCAR's CCM GCM does have problems simulating North American climate, even under present-day conditions (e.g. Bonan et al. 2002, using the most recent generation CCM). So although this incongruence may be due to an error inherent in the model, it is possible that it may indicate disequilibrium conditions between climate and the observed distribution of beech. Conditions $6000 \mathrm{yr}$ ago were warmer and drier than preceding and succeeding time periods (Webb 1992), and it is possible that cells modeled as 'presence' were suitable for beech, even though no beech was present and therefore no pollen recorded at the site.

The time frame of the $11 \mathrm{ka}$ scenario (11500 to 10500 BP) coincides with the end of the Younger Dryas event (12650 to $11500 \mathrm{BP}$; Björck et al. 1998). This period experienced unique climatic conditions and was bounded by abrupt changes in climate. The vegetation response to these climatic changes was rapid and more widespread than in any other millennia since the last glacial maximum (Shuman et al. 2002). Climate change varied regionally, with the mid-continent experiencing colder winters and warmer summers: conditions possibly with no modern analog. Plant taxa responded individualistically to the rapidly changing climate, by both shifting ranges and changing abundances, resulting in regional variations in community composition throughout eastern North America (Shuman et al. 2002). Given that these climatic changes occurred over such fine temporal and spatial scales, it is notable that a water budget approach, utilizing a GCM with $4.5^{\circ} \times 7.5^{\circ}$ resolution, correctly modeled $72 \%$ of study sites (Table 3 ).

Due to uncertainties in modeling past speciesclimate relationships, the results from any one modeling effort should be placed in context with other lines of evidence. The results of this research indicate that annual deficit and AET were able to delineate the range of beech better than traditional climatic variables. A water budget approach is attractive for modeling vegetation dynamics because it transcends issues of scale. It is widely accepted that ecological phenomena have characteristic scales, and that the nature of their explanatory variables changes with the scale of observation (e.g. Meentemeyer \& Box 1987, Wiens 1989). However, AET and deficit have proven useful in explaining the occurrence of beech at continental scales, as well as explaining its occurrence in plots within individual forest stands (Dyer 2002). Thus, not only are these variables ecologically meaningful across geographic scales, but they are measurable across a wide range of scales as well.

Acknowledgements. I would like to thank T. Owens for providing the program to calculate daily normal temperatures from monthly normals, and B. Bauer for providing a program to read tree-ring chronology records.

\section{LITERATURE CITED}

Alley WM (1984) The Palmer Drought Severity Index: limitations and assumptions. J Clim Appl Meteorol 23: 1100-1109

ASCE (American Society of Civil Engineers) (1990) Evapotranspiration and irrigation water requirements. American Society of Civil Engineers, New York

Bartlein PJ, Prentice IC, Webb T (1986) Climatic response surfaces from pollen data for some eastern North America taxa. J Biogeogr 13:35-57

Björck S, Walker MJC, Cwynar LC, Johnsen S, Knudsen KL, Lowe JJ, Wohlfarth B (1998) An event stratigraphy for the last termination in the North Atlantic region based on the Greenland ice-core record: a proposal by the INTIMATE group. J Quaternary Sci 13:283-292

Bonan GB, Oleson KW, Vertenstein M, Levis S, Zeng X, Dai Y, Dickinson RE, Yang ZL (2002) The land surface climatology of the community land model coupled to the NCAR community climate model. J Clim 15:3123-3149

Bouwman AF, Fung I, Matthews E, John J (1993) Global analysis of the potential for nitrous oxide $\left(\mathrm{N}_{2} \mathrm{O}\right)$ production in natural soils. Global Biogeochem Cycles 7:557-597

Box EO (1981) Macroclimate and plant forms: an introduction to predictive modeling in phytogeography. Dr. W. Junk Publishers, The Hague

Burns RM, Honkala BH (technical coordinators) (1990) Silvics of North America. USDA Forest Service Agricultural Handbook 654, US Government Printing Office, Washington, DC

Cook ER, Holmes RL (1999) Users manual for program ARSTAN. University of Arizona Laboratory of Tree-Ring Research, Tucson, AZ

Cramer WP, Leemans R (1993) Assessing impacts of climate change on vegetation using climate classification systems. In: Solomon AM, Shugart HH (eds) Vegetation dynamics and global change. Chapman \& Hall, New York, p 190-217

Davis MB, Zabinski C (1992) Changes in geographical range resulting from greenhouse warming: effects on biodiversity in forests. In: Peters RL, Lovejoy TE (eds) Global warming and biological diversity. Yale University Press, New Haven, CT, p 297-308

Davis MB, Woods KD, Webb SL, Futyma RP (1986) Dispersal versus climate: expansion of Fagus and Tsuga into the Upper Great Lakes region. Vegetatio 67:93-103 
Dyer JM (2002) A comparison of moisture scalars and water budget methods to assess vegetation-site relationships. Phys Geogr 23:245-258

Eyre FH (ed) (1980) Forest cover types of the United States and Canada. Society of American Foresters, Washington, DC

Fritts HC (1976) Tree rings and climate. Academic Press, New York

Greville TNE (1967) Spline functions, interpolation, and numerical quadrature. In: Ralston A, Wilf HS (eds) Mathematical methods for digital computers, Vol II. John Wiley \& Sons, New York, p 156-168

Holdridge LR (1947) Determination of world plant formations from simple climatic data. Science 105:367-368

Huntley B, Bartlein PJ, Prentice IC (1989) Climatic control of the distribution and abundance of beech (Fagus L.) in Europe and North America. J Biogeogr 16:551-560

Jacobson GL, Webb T, Grimm EC (1987) Patterns and rates of vegetation change during deglaciation of eastern North America. In: Ruddiman WF, Wright HE (eds) North America and adjacent oceans during the last deglaciation. Geological Society of America, Boulder, CO, p 277-288

Karl TR, Williams CN, Quinlan FT, Boden TA (1990) United States Historical Climatology Network (HCN) serial temperature and precipitation data. Environmental Science Division, Publication No. 3404. Carbon Dioxide Information and Analysis Center, Oak Ridge National Laboratory, Oak Ridge, TN

Lenihan JM (1993) Ecological response surfaces for North America boreal tree species and their use in forest classification. J Veg Sci 4:667-680

Little EL (1971) Atlas of United States trees, Vol 1. Conifers and important hardwoods. Misc. Publ. No. 1146. US Department of Agriculture Forest Service, Washington, DC

Loehle C, LeBlanc D (1996) Model-based assessments of climate change effects on forests: a critical review. Ecol Model 90:1-31

MacDonald GM (2003) Biogeography: space, time, and life. John Wiley \& Sons, New York

Manogaran C (1975) Actual evapotranspiration and the natural range of loblolly pine. Forest Sci 21:339-340

Mather JR (1974) Climatology: fundamentals and applications. McGraw-Hill, New York

Mather JR, Yoshioka GA (1968) The role of climate in the distribution of vegetation. Ann Assoc Am Geogr 58:29-41

Meentemeyer V, Box EO (1987) Scale effects in landscape studies. In: Turner MG (ed) Landscape heterogeneity and disturbance. Springer-Verlag, New York, p 15-34

Merriam CH (1894) Laws of temperature control on the geographic distribution of terrestrial animals and plants. Natl Geogr 6:229-238

Miller DA, White RA (1998) A conterminous United States multi-layer soil characteristics data set for regional climate and hydrology modeling. Earth Interactions 2:1-26. http://EarthInteractions.org

Editorial responsibility: Robert E. Davis,

Charlottesville, Virginia, USA
Overpeck JT, Bartlein PJ, Webb T (1991) Potential magnitude of future vegetation change in eastern North America: comparisons with the past. Science 254:692-695

Palmer WC (1965) Meteorological drought. Research Paper No. 45. US Department of Commerce Weather Bureau, Washington, DC

Pearson RG, Dawson TP (2003) Predicting the impacts of climate change on the distribution of species: are bioclimate envelope models useful? Global Ecol Biogeogr 12:361-371

Roth LC (1996) The plants behind the pixels: a commentary on Dyer's 'Implications of habitat fragmentation on climate-induced forest migration.' Prof Geogr 48:82-86

SAS Institute (1999) SAS/STAT user's guide, Version 8. SAS Institute, Cary, NC

Savage M, Brown PM, Feddema J (1996) The role of climate in a pine forest regeneration pulse in the southwestern United States. Ecoscience 3:310-318

Shafer SL, Bartlein PJ, Thompson RS (2001) Potential changes in the distributions of western North America tree and shrub taxa under future climate scenarios. Ecosystems 4: 200-215

Shuman B, Webb T, Bartlein P, Williams JW (2002) The anatomy of a climatic oscillation: vegetation change in eastern North America during the Younger Dryas chronozone. Quat Sci Rev 21:1777-1791

Stephenson NL (1990) Climate control of vegetation distribution: the role of the water balance. Am Nat 135:649-670

Stephenson NL (1998) Actual evapotranspiration and deficit: biologically meaningful correlates of vegetation distribution across spatial scales. J Biogeogr 25:855-870

Thornthwaite CW (1948) An approach toward a rational classification of climate. Geogr Rev 38:55-94

Webb $\mathrm{T}$ (1992) Past changes in vegetation and climate: lessons for the future. In: Peters RL, Lovejoy TE (eds) Global warming and biological diversity. Yale University Press, New Haven, CT, p 59-75

Wiens JA (1989) Spatial scaling in ecology. Funct Ecol 3: 385-397

Williamson DL, Kiehl JT, Ramanathan V, Dickinson RE, Hack JJ (1987) Description of NCAR Community Climate Model (CCM1). NCAR Technical Note, NCAR/TN-285+STR. National Center for Atmospheric Research, Boulder, CO

Willmott CJ (1977) WATBUG: a FORTRAN IV algorithm for calculating the climatic water budget. In: Publications in climatology. CW Thornthwaite Associates Laboratory of Climatology, Elmer, NJ

WDC (World Data Center for Paleoclimatology) (2003a) Contributors of the International Tree-Ring Data Bank, IGBP PAGES/World Data Center for Paleoclimatology, NOAA/NGDC Paleoclimatology Program. Boulder, CO. www.ngdc.noaa.gov/paleo/data.html

WDC (World Data Center for Paleoclimatology) (2003b) Contributors of the NAPD, IGBP PAGES/World Data Center for Paleoclimatology, NOAA/NGDC Paleoclimatology Program. Boulder, CO. www.ngdc.noaa.gov/paleo/data.html

Submitted: February 26, 2004; Accepted: October 19, 2004

Proofs received from author(s): December 20, 2004 